\title{
THE EFFECTS OF FINANCIAL DEVELOPMENT ON ECONOMIC GROWTH IN AFRICA: DOES THE QUALITY OF INSTITUTIONS MATTER?
}

\author{
DOI: 10.17261/Pressacademia.2021.1462 \\ JBEF-V.10-ISS.4-2021(3)-p.166-177
}

\section{Nega Muhabaw Kassie}

Marmara University, Department of Economics, Goztepe Campus, Istanbul, Turkey. nmuhaba@gmail.com, ORCID: 0000-0003-0416-6588

\begin{tabular}{l} 
Date Received: October16, , $2021 \quad$ Date Accepted: December 20, 2021 \\
\hline To cite this document \\
Kassie, N.M., (2021). The effects of financial development on economic growth in Africa: does the quality of institutions matter? Journal of \\
Business, Economics and Finance (JBEF), $10(4), 166-177$. \\
Permanent link to this document: http://doi.org/10.17261/Pressacademia.2021.1462 \\
Copyright: Published by PressAcademia and limited licensed re-use rights only.
\end{tabular}

\section{ABSTRACT}

Purpose- The main objective of this paper is twofold. First, the paper aims to examine the effect of financial development on the economic growth of African countries. Second, the paper also aims to examine if institutional quality moderates the nexus between financial development and growth.

Methodology- A panel dataset of 35 African countries over the period from 1985 through 2018 is used and to handle the problem of endogeneity and reverse causality the dynamic panel estimation method, GMM estimation, was employed to estimate the relationship while accounting for other control variables that affect economic growth. The data set was retrieved from World Bank world development indicators, international monetary fund, and International Country Risk Guide (ICRG).

Findings- The empirical results of the study indicate that financial development has an ambiguous impact on the economic growth of African countries, but it has a significant positive effect on growth if interacted with the institutional quality index such as government stability, rule of law, and corruption. The interaction term between finance and institutional quality indicator is positive and significant, implying that the positive effect of financial development depends on the level of institutional quality of the country.

Conclusion- To sum up, in countries where institutional quality is high, the effect of financial development on growth is higher compared to countries where institutional quality is low. This indicates that improving institutional quality is essential to reap the benefit of financial development in Africa. It is thus vital for African countries to engage in drafting various programs and strategies to improve institutional quality so as to improve growth.

Keywords: Financial development, economic growth, Africa, institutional quality JEL codes: G10, G20, E44

\section{INTRODUCTION}

Ever since Bagehot (1873), the nexus between finance and economic growth has been a widely researched area in development economics. It has been argued that a developed financial system can facilitate industrialization by enabling capital mobilization and allocating it to the productive investment sector. In the same vein, Schumpeter (1911) highlighted the eminent role of the country's financial system for economic development as it distributes funds to productive investment. Well-developed financial institutions like banks and financial markets have a great contribution to bringing domestic savers and investors together and conveying information. Likewise, Levine (2005) suggested that financial development enhances economic growth through mobilization of savings, improving capital accumulation, optimizing resource allocation, and facilitating innovation. The developed financial sector is said to reduce costs by producing information ex-ante about possible investments and improving resource allocation, monitoring investments and exerting corporate governance, and facilitating trade and asset diversification. It is in this respect that several empirical studies indicated a positive relationship between economic growth and financial development indicators ${ }^{1}$.

\footnotetext{
${ }^{1}$ See King and Levine (1993), R. G. Rajan and Zingales (1996), Levine (1999),Arestis, Demetriades, and Luintel (2001), Beck and Levine (2002)
} 
Although earlier studies documented empirical evidence in favor of the positive effect of finance on growth, recent studies have produced mixed results. More specifically, the overwhelming majority of the studies indicated that the positive effect of financial sector development on economic growth depends upon the presence of other complementary environments in the country such as human capital, good governance, and institutional quality (Ibrahim \& Alagidede, 2018). In this regard, it has been argued that in countries where institutional quality is high, financial development has a significant positive effect on economic growth while it has a negative impact in countries where institutional quality is low (Demetriades and Hook Law (2006); (Kutan, Samargandi, \& Sohag, 2017). Although studies on this realm have increased significantly in the last decades, the debate still continues as to which of the complementary environment is important. In addition, it is also unclear whether the mediating role of institutional quality on the nexus between financial development and growth varies depending on the type of financial development indicators considered: financial institutions Vs financial market. It is more pronounced in Africa, where empirical studies in this matter are extremely limited. It is against this backdrop that this paper examines the relationship between financial development and economic growth of sub-Saharan African countries focusing on the moderating role of institutional quality. More specifically, this paper attempts to answer the following research questions: (1) Does financial development promote economic growth in Africa; and (2) Does the quality of institutions matter in the nexus between finance and growth. To this end, a secondary dataset from WDI, IMF, and ICRG was collected for a panel of 35 African countries over the period 1985 to 2018, and the GMM estimation method was employed to handle the problem of endogeneity and reverse causality. The empirical results of the study indicate that financial development has an ambiguous impact on the economic growth of African countries. Most of the models considered financial development has an insignificant impact on growth, even it has a significant negative impact when institutional quality is included in the growth model. The interaction term between finance and institutional quality indicator is positive and significant, implying that the positive effect of financial development depends on the level of institutional quality of the country. Therefore, it can be concluded that not only that the quality of the institutions is vital for the economic growth of African countries but it is also essential for reinforcing the positive effect of finance on economic growth.

The current study contributes to the existing literature in many ways. First, unlike most of the previous studies that used a single measure of financial development, this study analyzed the effect of financial development on economic growth using a recently developed financial development proxy that takes into account the multidimensional nature of financial development. The financial development proxy variable developed by (Sahay et al., 2015) and then (Svirydzenka, 2016) accounts for the depth, access, and efficiency of both financial institutions and markets. ${ }^{2}$ So far, very few studies have used this indicator to analyze the nexus between finance and growth, ignoring the multifaceted nature of financial development. Second, this study focuses on the sample of African countries to examine the effect of finance and economic growth. The overwhelming majority of previous studies in this realm has emphasized in the case of developed and emerging countries. As such, little is yet known for the case of developing countries, more specifically Africa. Therefore, the current study adds to the scant literature available. The remainder of this paper is organized as follows. The next section discusses the literature review while the third section presents the data and the empirical methodology used in this study. The fourth section presents the discussion of empirical results and the last section provides a conclusion and policy recommendation.

\section{LITERATURE REVIEW}

There is an enormous theoretical and empirical study that demonstrates the positive impact of financial development on the economic growth of countries. Well-functioning financial institutions and markets are believed to enhance economic growth through lowering transaction costs, fastening transactions, improving capital accumulation, and allocating investments into the most productive sector of the economy (Choong \& Chan, 2011; Fernández \& Tamayo, 2017; Levine, 1997). The pioneering empirical study by King and Levine (1993) indicates that financial development indicators such as percentage of credit allocated to private firms, the size of the formal financial intermediary sector relative to GDP, the ratio of credit issued to private firms to GDP, and the importance of banks relative to the central bank has a significant positive effect on economic growth using a sample of 80 countries over the period 1960 to 1989. Likewise, Arestis et al. (2001) found that financial development promotes economic growth for five developed economies, namely Germany, the United States, Japan, the United Kingdom, and France. Other pertinent studies, such as (Beck \& Levine, 2002; Levine, 1999; R. G. Rajan \& Zingales, 1996) found a significant positive relationship between financial development and economic growth. In the same vein, Levine (2002) Provides further evidence on the overall financial development robustly linked with economic growth. Levine, Loayza, and Beck (2000) showed that exogenous components of financial intermediary development are positively associated with economic growth. Along similar lines, Beck, Levine, and Loayza (2000) suggested that financial intermediaries exert a large, positive impact on total factor productivity growth, which feeds through to overall GDP growth. R. G. Rajan and Zingales (1996) also revealed that financial development has

\footnotetext{
${ }^{2}$ We adapted the work of Svirydzenka (2016) to demonstrate the financial development index triquetral presented in the appendix 1 , that accounts for both financial institutions and financial market with several classifications.
} 
a substantial supportive influence on the rate of economic growth and this works, at least partly, by reducing the cost of external finance to financially dependent firms.

Despite the fact that previous empirical studies suggested the positive and significant impact of financial development on economic growth, recent studies challenge the previous findings. For instance, Rousseau and Wachtel (2011) reexamine the effect of financial depth on economic growth using both panel and cross-sectional approaches for the period 1965 to 2004 and find that financial development proxied by credit to the private sector and financial depth does not have a statistically significant impact on economic growth. The other strand of literature highlighted a "hump-shaped" linkage between finance and economic growth (Deidda \& Fattouh, 2002; Law, Azman-Saini, \& Ibrahim, 2013; Law \& Singh, 2014; Rioja \& Valev, 2004; Shen \& Lee, 2006). For instance, Rioja and Valev (2004) conducted an empirical investigation on the nexus between financial development and economic growth using a sample of 74 countries over the period 1960 to 1995 by dividing countries into three groups (high, intermediate, low levels of financial development). The author found a strong positive relationship between finance and growth for countries at the intermediate level of financial development. For countries at a higher level of financial development, the author found a positive but weak relationship and uncertain effect of financial market improvement on growth in countries where financial development is at a low level of financial development. In the same vein, Deidda and Fattouh (2002) revealed that there is no significant relationship between financial development and economic growth in low-income countries whereas a positive and significant relationship was found in high-income countries. This implies that the effect of financial development varies depending on the economic level of countries. In the same line of argument, Huang and Lin (2009) employed a threshold regression to reexamine how the stage of economic development of the country affects the nexus between finance and growth. The author found a significant positive effect of financial development on economic growth in both low and high-income countries but its effect is higher in low-income countries than in developed countries. Another line of studies found that financial development has a positive effect on growth up to a certain threshold beyond which it has no significant impact. For instance, Cecchetti and Kharroubi (2012) found that financial development is good only up to a certain level, after that it has a negative effect on growth, implying an inverted U-shape relationship between finance and growth.

The other strand of the literature indicated that the effect of finance on economic growth is mediated by the country-specific environment such as inflation level, governance, and institutional quality, to mention a few. This line of studies argued that for financial development to be useful for the economic transformation of the country, there should be other pertinent macroeconomic factors to be present. For instance, Rousseau and Wachtel (2002) indicated that the positive effect of finance on economic growth is dependent on the rate of inflation. Using a panel dataset of 84 countries for the period 1960-1995, the author found that in countries where the inflation rate is one-digit, financial development has a significant positive effect. In countries where the inflation rate is two digits, financial depth does not have a significant impact on economic growth of countries. . In a similar vein, Shen and Lee (2006) investigate how financial and economic conditional variables affect the link between financial development and real GDP per capita growth on 48 developed and developing countries, The author found an inverted $U$ shape relationship between financial development and economic growth. Employing a panel threshold regression for 71 countries over the period 1960 to 2004. Jude (2010) noted that the relationship between financial development and growth is non-linear and the relationship is significantly moderated by openness, government consumption, and inflation rate.

A recent study by Arcand et al. (2015) also indicates that the inverted $U$ shape relationship between financial development and economic growth. The author employed different empirical approaches and used various datasets to assess the threshold level in which financial depth has no effect on economic growth. The author found that financial development has a positive effect on growth to the point where private sector credit to a percentage of GDP reaches 100 . According to the author, beyond this point, further development of the financial sector has a significant negative impact on growth. Similar results were found by Law and Singh (2014). The authors employed a dynamic panel threshold technique for a sample of 87 developing and developed countries and found that the level of financial development has a positive impact on growth only within a certain threshold level; apart from that finance affects growth negatively Aizenman, Jinjarak, and Park (2015) analyze the nexus between finance and growth in 41 countries, specifically comparing the outcome of Latin American economies and east Asia, at a sectoral level, and finds anon linear link between financial development and sectoral output growth. De Gregorio and Guidotti (1995) investigate the link between financial development and long-run growth in a large cross-country sample. The author found that financial development positively related to the long-run growth of real GDP per capita in low and middle-income economies but a fragile relationship in high-income countries. They also noticed a negative relationship between variables in panel data from Latin American countries. The negative relationship is attributed to financial liberalization in poor regulation. Using a sample of 43 developing and advanced economies for the period 1975 to 2009 Doumbia (2016) has also suggested that financial development has a positive and significant impact on growth in low income and lower-middle-income economies through facilitating saving and investment but it has a weaker effect in more developed economies.

Demetriades and Hook Law (2006) used data from 72 countries for the period 1978-2000 and found that financial development has a greater impact on economic growth when the financial system is entrenched with good institutions. In countries with low 
institutional quality, more finance doesn't produce more economic growth. Recently, Botev, Égert, and Jawadi (2019) estimated a nonlinear threshold regression model to investigate the nexus between financial development and economic growth \found that the effect of financial development on economic growth is determined by the level of trade openness and overall economic development. In countries where the level of trade openness is higher, financial development has a significant positive effect while no significant effect in countries where trade oneness is low, using the threshold estimation method Law et al. (2013) also reach the same conclusion that the positive and significant effect of finance on growth occurs only countries with a higher level of institutional quality but no significant impact in countries with a low level of institutional quality, implying that the nexus between finance and economic growth is dependent on the level of institutional quality.

To conclude, several empirical studies have provided substantial evidence on the positive relationship between financial development and economic growth. However, absence of general consent on the factors that leads to this finance-growth nexus. This study assesses the importance of institutional quality on the linkage between finance and growth in Africa and brings attention to future research.

\section{DATA AND EMPIRICAL METHODOLOGY}

\subsection{Data Description}

We relied on the secondary data source to examine the impact of financial development on the economic growth of African countries. The data is retrieved from three sources: (i) data on macroeconomic variables such as GDP per capita, saving, human capital, which is from WB's WDI; (ii) Financial Development Index is from IMF; (iii) and the institutional variables are retrieved from ICRG. The study utilizes a panel data set of 35 African countries over the period from 1985 through 2018

\subsection{Empirical Model}

To examine the moderating role of institutional quality on the nexus between finance and growth, we use the following regression model following recent studies in this realm ( King \& Levine, 1993; Levine \& Zervos, 1998; Cecchetti \& Kharroubi, 2012; Law et al., 2013). Thus the linear model in our case is given by:

$y_{i t}=\pi_{i}+\rho y_{i t-1}+\beta_{0}+\beta_{1} F D_{i t}+\beta_{2} I Q_{i t}+\beta_{3} F D_{i t} * I Q_{i t}+\beta_{3} X_{i t}+\varepsilon_{i t}$

Where, $y_{i t}$ is the GDP per capita, $\pi_{i}$ is country-specific fixed effect term, $\beta_{0}$ is the constant term, $F D_{i t}$ is financial development indicators, $I Q_{i t}$ reflects institutional quality indicator variables, $X_{i t}$ is a vector of control variables that determine economic growth, namely population, openness, investment, government expenditure, human capital, and inflation and $\varepsilon_{i t}$ is the error term.

A significant and positive coefficient of FD $\left(\beta_{1}\right)$ indicates the positive effect of financial development on economic growth. Although most of the previous studies have indicated the positive effect of financial development, there is a counter-argument to this claim. Therefore, our prior expectation is not inconclusive. It is empirically and theoretically argued that financial development can influence economic growth through institutional quality (Ibrahim \& Alagidede, 2018). In this regard, good institutional has a significant contribution to enhancing the positive effect of financial development on growth. To test this hypothesis, the interaction term between financial development and institutional quality has been included. In the same vein, a significant and positive value of $\beta_{3}$ is an indication that the nexus between finance and growth is moderated by country-level institutional quality.

Previous literature suggested various methods of estimation of the growth equation including, but not limited to, pooled OLS, fixed effect, and GMM. In our model (see equation 1), the lag of the dependent variable is included as one control variable to test for the convergence hypothesis. It also indicates that today's economic growth is affected by the growth rate of last year. Estimating such kind of econometric specification using pooled OLS produces a biased estimate because the lagged value of GDP growth is correlated to the error term. As indicated in Roodman (2009), pooled OLS attributes to the country fixed effect to the lagged dependent variable. To circumvent this problem, one can account for country fixed effect using a panel fixed effect estimator. The panel fixed effect estimator will still be biased if one of the independent variables is endogenous because the endogenous variable will be correlated with the error term. In fact, the lagged dependent variable is endogenous and it is possible that it is correlated to the error term. This results in a lower coefficient of the lag dependent variable compared to the true value.

The estimator that addresses both heterogeneity and endogeneity is GMM. Two types of GMM are suggested in the literature. The first is difference GMM that employs data transformation into its first difference to get rid of the problem of heterogeneity and uses lagged value of the endogenous variable to remove the problem of endogeneity. Although this estimator addresses the limitation of both pooled OLS and fixed effect estimation, it has one major limitation i.e. the lagged value of the variables are poor instruments. The second estimator is System GMM. System GMM uses both the lagged value of the endogenous variables and also the lag of the first difference of endogenous as an additional instrument. The use of the lagged value of endogenous 
variable improves the efficiency of the estimator. As suggested in the literature (Roodman, 2009), this study relies on system GMM estimation to drive conclusions and recommendations but present the result of the other estimators for the purpose of comparisons.

The following table (Table 1) provides the list of variables used in this study and its description.

Table 1: Description of Variables

\begin{tabular}{|c|c|c|}
\hline Variable & Description & Expected sign \\
\hline L.Ingdppcw & log of GDP per capita growth & Inconclusive \\
\hline FD & Financial development & Positive \\
\hline Inopen & $\begin{array}{l}\text { log of trade openness as percentage of } \\
\text { GDP }\end{array}$ & Positive \\
\hline Ininv & log of investment as percentage of GDP & Positive \\
\hline hc & Human capital indicator & Positive \\
\hline Gov_Stab & Government stability & Positive \\
\hline Inv_Pro & Investment profile & Positive \\
\hline Corr & Corruption & Positive \\
\hline Law_Order & Law and order & Positive \\
\hline Mil_Pol & Military in politics & Positive \\
\hline Demo_Acc & Democratic Accountability & Positive \\
\hline Bure_Qua & Bureaucratic Quality & Positive \\
\hline
\end{tabular}

\section{DISCUSSION AND EMPIRICAL RESULTS}

\subsection{Descriptive statistics}

Table 2 below demonstrates the descriptive statistics for all macroeconomic, financial, and institutional quality variables. As shown in the table, the mean log of real GDP per capita is 7.05 and the minimum and the maximum are 5.2 and 9.34 respectively. It should be noted that the indicator of financial development is between 0 and 1 . The higher the value, the higher level of financial development it represents. As shown in Table 2.2 the average level of financial development for the sample is 0.14 while the minimum being 0 and the maximum 0.6, indicating that most countries in Africa are at the lower level of the financial development stage. The mean value of the log of trade openness, which is measured as the ratio of import and export to GDP, is 4.05 with a standard deviation of 0.41 . Looking into indicators of institutional quality indicates that the average value of government stability is 7.5 with a standard deviation of 2.04 . In the same vein, the average value of the investment profile is 6.7 , and the standard deviation 1.81 .

Table 2: Summary Statistics

\begin{tabular}{lllll}
\hline Variable & Mean & Standard deviation & Minimum & Maximum \\
\hline Ingdppcw & 7.054 & 0.999 & 5.215 & 9.344 \\
FD & 0.140 & 0.094 & 0 & 0.609 \\
Inopen & 4.059 & 0.412 & 2.626 & 5.042 \\
Ininv & 2.952 & 0.425 & 0.730 & 3.915 \\
hc & 1.649 & 0.425 & 1.026 & 2.848 \\
Institutional quality variables & 7.576 & 2.014 & & 11 \\
Gov_Stab & 6.747 & 1.810 & 2.167 & 11.438 \\
Inv_Pro & 2.318 & 0.873 & 1.542 & 5.334 \\
Corr & 2.904 & 1.018 & 0 & 6 \\
Law_Order & 2.557 & 1.524 & 0.667 & 6 \\
Mil_Pol & 2.977 & 1.070 & 0 & 5.407 \\
Demo_Acc & 1.442 & 0.869 & 0 & 4 \\
Bure_Qua & & & 0 & 4 \\
\hline
\end{tabular}

\subsection{Correlation matrix}


Table 3 presents the correlation matrix, the linear association between two variables. As indicated in the correlation matrix, most of the variables have a significant positive correlation between financial development and its correlates. Referring to the correlation matrix, the insightful association is detected for financial development and its correlates. This is in line with empirical studies discussed in the literature part ( see, Beck \& Levine, 2002; Levine, 1999; R. G. Rajan \& Zingales, 1996 ).

Table 3: Correlation Matrix

\begin{tabular}{|c|c|c|c|c|c|c|c|c|c|c|}
\hline Variables & & (2) & (3) & (4) & (5) & (6) & (7) & (8) & (9) & (10) \\
\hline (1) L.Ingdppcw & 1.000 & & & & & & & & & \\
\hline (2) Ininv & $0.412^{*}$ & 1.000 & & & & & & & & \\
\hline (3) FD & $0.517^{*}$ & $0.227^{*}$ & 1.000 & & & & & & & \\
\hline (4) Gov_Stab & 0.121 & $0.148 *$ & $0.152^{*}$ & 1.000 & & & & & & \\
\hline (7) Law_Order & 0.072 & $0.148^{*}$ & $0.231 *$ & $0.318^{*}$ & $0.374^{*}$ & $0.264 *$ & 1.000 & & & \\
\hline (8) Mil_Pol & $0.304 *$ & $0.218^{*}$ & $0.410^{*}$ & 0.034 & $0.411 *$ & $0.433^{*}$ & $0.372^{*}$ & 1.000 & & \\
\hline (9) Demo_Acc & $0.167^{*}$ & $0.243^{*}$ & $0.334 *$ & $0.151^{*}$ & $0.412 *$ & $0.154 *$ & $0.243^{*}$ & $0.499 *$ & 1.000 & \\
\hline
\end{tabular}

\subsection{EMPIRICAL RESULTS}

\subsubsection{Financial Development and Economic Growth}

The regression results of the study are presented in Table 4. The first column of Table 4 presents the estimation result using pooled OLS; column two presents fixed effect estimation results; column three reports the estimation results of difference GMM, and column four of Table 4 reports the results of estimation results. As discussed earlier, the OLS estimation method is biased because of the lag of the dependent variable. However, it is presented here for the purpose of comparison. It indicates that financial development has a significant positive impact on economic growth. This result is not reliable because it ignores country heterogeneity and the dynamic nature of the growth equation. In order to account for country heterogeneity using country dummies, the same growth equation is estimated using fixed effect and the result is presented in the second column. The coefficient of FD using fixed effect is negative and insignificant at the conventional significance level, indicating the fact that the importance of financial development dwindles as country heterogeneity is taken into consideration.

Despite its superiority over OLS, the fixed effect estimation method is also subjected to an endogeneity problem. The estimation result from the fixed effect is biased if one of the independent variables is endogenous. In our case, both the lag of the dependent variable and financial development are endogenous. The most widely approach to circumvent the endogeneity problem is the GMM estimation method. The endogeneity problem is alleviated through instrumental estimation techniques. In the GMM environment often we use lag values of the endogenous variables as instruments. There are two types of GMM estimation methods: Difference GMM and system GMM. In this study, we used system GMM instead of difference GMM to capture endogeneity through forwarding orthogonal deviation transformation and to eliminate the serial correlation between transformed errors. Column 3 of the following table presents the estimation results of difference GMM and indicates that financial development has no significant impact on the economic growth of SSA countries. In the same vein, the result of system GMM estimation is presented in column 4. Although the coefficient of financial development is positive, it is insignificant at a conventional significance level.

Table 4: Estimation Results of the Growth Equation 


\begin{tabular}{lcccc}
\hline & $\begin{array}{c}(\mathbf{1}) \\
\text { pooled_OLS }\end{array}$ & $\begin{array}{c}(\mathbf{2}) \\
\text { fixed } \\
\text { Dependent variable: Ingdppcw }\end{array}$ & $\begin{array}{c}\text { (3) } \\
\text { diff_GMM } \\
\text { Sys_GMM }\end{array}$ \\
\hline L.Ingdppcw & $0.987^{* * *}$ & $0.936^{* * *}$ & $0.924^{* * *}$ & $0.961^{* * *}$ \\
FD & $(0.00217)$ & $(0.00907)$ & $(0.0149)$ & $(0.0101)$ \\
& $0.0558^{* * *}$ & -0.00464 & -0.0446 & $(0.0398$ \\
Lnopen & $(0.0177)$ & $(0.0448)$ & $(0.0695)$ & 0.00585 \\
Lninv & 0.00195 & $0.0327^{* * *}$ & $0.0323^{* * *}$ & $(0.00806)$ \\
Hc & $(0.00365)$ & $(0.00633)$ & $(0.00645)$ & $0.0257^{* * *}$ \\
& $0.0204^{* * *}$ & $0.00901^{* *}$ & $0.00965^{* *}$ & $(0.00494)$ \\
Constant & $(0.00337)$ & $(0.00415)$ & $(0.00418)$ & $0.0470^{* *}$ \\
& $0.0119 * * *$ & $0.0483^{* * *}$ & $0.0675^{* * *}$ & $(0.0186)$ \\
\hline Observations & $(0.00455)$ & $(0.00915)$ & $(0.0123)$ & $0.102^{*}$ \\
R-squared & 0.00798 & $0.227^{* * *}$ & & $(0.0543)$ \\
Number of code1 & $(0.0154)$ & $(0.0572)$ & & 818 \\
\hline
\end{tabular}

Standard errors in parentheses

$* * * p<0.01, * * p<0.05, * p<0.1$

The significance and the sign of the remaining coefficients are as expected. As can be seen from the table, investment has a significant and positive impact on economic growth. Similarly, human capital has a significant and positive impact on the economic growth of the region, implying enhancing human capital and boosting the level of investment would improve the economic performance of African countries, and this, in turn, reduces poverty.

To conclude, our empirical investigation indicates that there is no statistically significant relationship between financial development and economic growth if both endogeneity and country heterogeneity is taken into account. Parallel with that, our results are consistent with the findings of Deidda \& Fattouh, 2002. Implying that, the estimation results nullify the financial development economic growth linkages. The only difference noted is in our study results corroborates that the link varies when institutional variables are considered as Law, 2013 explained.

\subsubsection{Financial Development, Institutional Quality and Economic Growth}

Our empirical investigation so far examines the impact of financial development and other control variables on economic growth. It has been suggested in growth literature that institutional quality is one of the main determinants of growth. Thus, an empirical investigation is done including the measure of institutional quality variable in the growth equation and the results are presented in the appendix (appendix 2). It is to be noted that each institutional indicator is included separately in the growth equation because institutional variables are highly correlated to each other and including them simultaneously will result in a multicollinearity problem. The following table presents the empirical results of the system GMM estimation. As shown in the table, all of the institutional variables, except democratic accountability and bureaucratic quality, have a significant positive coefficient, implying the positive effect of institutions on economic growth.

Our variable of interest, FD, is positive but insignificant at the usual significance level. This implies there is no significant relationship between financial development and economic growth even after controlling for a wide range of control variables including intuitional, human capital, physical capital, and trade openness. The sign and the significance of other control variables remain the same as our previous estimation results.

\subsubsection{The Moderating Effect of Institutional Quality on the Nexus between Financial Development and Economic Growth}

The second aim of the study is to investigate if the effect of financial development on economic growth is moderated by institutional quality. To this end, the financial development variable has interacted with the institutional variable in the growth equation and the results are presented in the appendix (appendix 3 ). The first column of the following table presents the results of the growth equation with the inclusion of the interaction between financial development and government stability. The coefficient is positive and significant, implying financial development has a profound positive impact on economic growth in countries where government stability is higher. The second column presents the GMM estimation results when the investment profile has interacted with financial development. As expected, the estimation results indicated that financial development has 
a significant positive impact on growth in countries where the investment profile is higher. In addition to these institutional variables, the study finds that law and order, military in politics, and bureaucratic quality moderate the effect of financial development on economic growth.

\section{CONCLUSIONS AND RECOMMENDATION}

Earlier studies indicated that financial development significantly improves the economic development of the country. Recent studies, however, showed that the positive effect of the financial sector is dependent on the presence of other complementary environments in the country such as human capital, good governance, and institutional quality. The main aim of the current study is thus to empirically verify the hypothesis that institutional quality moderates the nexus between financial development and economic growth. For this purpose, panel data of SSA countries were used and the secondary data obtained from the World development indicator and ICRG datasets is estimated using the dynamic panel estimation method.

The findings of the study indicate that financial development does not have a significant impact on economic growth, regardless of whether the institutional quality index is included in the regression as one control variable or not. However, when interacted with institutional quality indicators such as government stability, rule of law, and corruption, it has a significant positive effect on economic growth. This indicates that the effect of financial development on economic growth is dependent on the level of institutional quality of the country. In countries where institutional quality is high, the effect of financial development on growth is higher compared to countries where institutional quality is low.

The evidence from this study suggests that countries in SSA should exert more effort to improve institutional quality in order to reap the benefit of financial development. Not only that institutional quality moderate the nexus between financial development and economic growth but also institutions have a direct impact on economic growth as evidenced by the significant positive value of the institutional indicator in the estimation. The result of this study supports the idea that investment in human and physical capital is also important to accelerate economic growth in the region.

\section{REFERENCES}

Aizenman, J., Jinjarak, Y., \& Park, D. (2015). Financial development and output growth in developing Asia and Latin America: A comparative sectoral analysis (No. w20917). National Bureau of Economic Research.

Arcand, J. L., Berkes, E., \& Panizza, U. (2015). Too much finance? Journal of Economic Growth, 20(2), 105-148.

Arestis, P., \& Demetriades, P. (1997). Finance and growth: institutional considerations and causality. Available at SSRN 35996.

Arestis, P., Demetriades, P. O., \& Luintel, K. B. (2001). Financial development and economic growth: the role of stock markets. Journal of Money, credit, and banking, 16-41.

Beck, T., \& Levine, R. (2002). Industry growth and capital allocation: does having a market-or bank-based system matter? Journal of Financial Economics, 64(2), 147-180.

Beck, T., Levine, R., \& Loayza, N. (2000). Finance and the Sources of Growth. Journal of Financial Economics, 58(1-2), 261-300.

Botev, J., Égert, B., \& Jawadi, F. (2019). The nonlinear relationship between economic growth and financial development: Evidence from developing, emerging and advanced economies. International Economics, 160, 3-13.

Cecchetti, S. G., \& Kharroubi, E. (2012). Reassessing the impact of finance on growth (No. 381). Bank for international settlements.

De Gregorio, J., \& Guidotti, P. E. (1995). Financial development and economic growth. World Development, 23(3), 433-448.

Deidda, L., \& Fattouh, B. (2002). Non-linearity between finance and growth. Economics Letters, 74(3), 339-345.

Demetriades, P., \& Hook Law, S. (2006). Finance, institutions, and economic development. International Journal of Finance \& Economics, 11(3), $245-260$.

Demetriades, P. O., \& Hussein, K. A. (1996). Does financial development cause economic growth? Time-series evidence from 16 countries. Journal of Development Economics, 51(2), 387-411.

Doumbia, D. (2016). Financial development and economic growth in 43 advanced and developing economies over the period 1975-2009: Evidence of non-linearity. Applied Econometrics and International Development, 16(1), 13-22.

Huang, H. C., \& Lin, S. C. (2009). Non-linear finance-growth nexus: A threshold with instrumental variable approach 1. Economics of Transition, 17(3), 439-466.

Ibrahim, M., \& Alagidede, P. (2018). Nonlinearities in financial development-economic growth nexus: Evidence from sub-Saharan Africa. Research in International Business and Finance, 46, 95-104.

Jude, E. C. (2010). Financial development and growth: A panel smooth regression approach. Journal of Economic Development, 35(1), 15. 
King, R. G., \& Levine, R. (1993). Finance and growth: Schumpeter might be right. The quarterly journal of economics, 108(3), 717-737.

Kutan, A. M., Samargandi, N., \& Sohag, K. (2017). Does institutional quality matter for financial development and growth? Further evidence from MENA countries. Australian Economic Papers, 56(3), 228-248.

Law, S. H., Azman-Saini, W., \& Ibrahim, M. H. (2013). Institutional quality thresholds and the finance-growth nexus. Journal of Banking \& Finance, 37(12), 5373-5381.

Law, S. H., \& Singh, N. (2014). Does too much finance harm economic growth? Journal of Banking \& Finance, 41, 36-44.

Levine, R. (1999). Financial Development and Economic Growth: Views and Agenda, World Back Policy Research Working Paper, No. 178. World Bank, Washington DC.

Levine, R. (2002). Bank-based or market-based financial systems: which is better? Journal of Financial Intermediation, 11(4), $398-428$.

Levine, R. (2005). Finance and growth: theory and evidence. Handbook of Economic Growth, 1, 865-934.

Levine, R., Loayza, N., \& Beck, T. (2000). Financial intermediation and growth: Causality and causes. Journal of Monetary Economics, 46(1), 3177.

Rajan, R. G., \& Zingales, L. (1996). Financial dependence and growth. American Economic Review, Vol. 88, no. 3 (1998): 559-586

Rioja, F., \& Valev, N. (2004). Does one size fit all? A reexamination of the finance and growth relationship. Journal of Development Economics, 74(2), 429-447.

Roodman, D. (2009). How to do xtabond2: An introduction to difference and system GMM in Stata. The State Journal, 9(1), 86-136.

Rousseau, P. L., \& Wachtel, P. (2002). Inflation thresholds and the finance-growth nexus. Journal of International Money and Finance, 21(6), 777-793.

Rousseau, P. L., \& Wachtel, P. (2011). What is happening to the impact of financial deepening on economic growth? Economic Inquiry, 49(1), 276-288.

Sahay, R., Čihák, M., N'Diaye, P., \& Barajas, A. (2015). Rethinking financial deepening: Stability and growth in emerging markets. Revista de Economía Institucional, 17(33), 73-107.

Schumpeter, J. A. (1911). The Theory of Economic Development. Repr., Cambridge, MA: Harvard University Press, 1934.

Shen, C.-H., \& Lee, C.-C. (2006). Same financial development yet different economic growth: why? Journal of Money, Credit, and Banking,Vol. 38, No. 7 (Oct., 2006) pp. 1907-1944

Svirydzenka, K. (2016). Introducing a New Broad-based Index of Financial Development (No. 2016/005). International Monetary Fund.

\section{Appendix 1: Financial Development Index Triquetral}




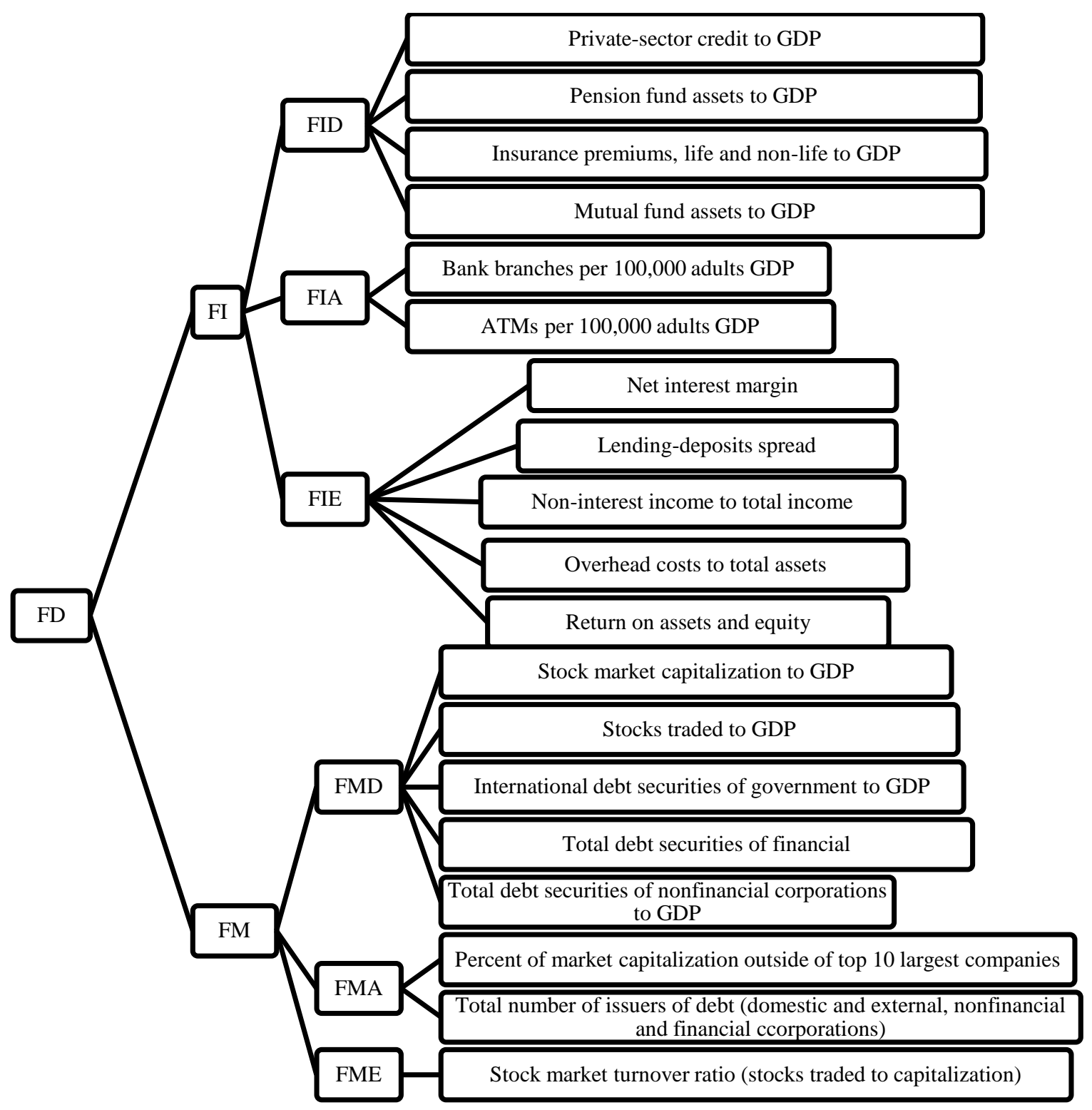

Note: $F D=$ financial development $; F I=$ financial institutions; $F M=$ financial markets; $F I D=$ financial institutions depth; $F I A=$ financial institutions access; $F I E$ = financial institutions efficiency; $F M D$ = financial markets depth; FMA = financial markets access; FME financial markets efficiency. 
Appendix 2: System GMM Estimation with Institutional Variables

\begin{tabular}{|c|c|c|c|c|c|c|c|}
\hline \multirow{2}{*}{ VARIABLES } & (1) & (2) & (3) & (4) & (5) & (6) & (7) \\
\hline & \multicolumn{7}{|c|}{ Dependent Variable: Ingdppcw } \\
\hline \multirow[t]{2}{*}{ L.Ingdppcw } & $0.980 * * *$ & $1.013^{* * *}$ & $0.788^{* * *}$ & $0.976^{* * *}$ & $0.896^{* * *}$ & $1.000 * * *$ & $0.856^{* * *}$ \\
\hline & (0.00796) & $(0.0189)$ & $(0.0823)$ & $(0.0152)$ & $(0.0458)$ & $(0.0422)$ & (0.105) \\
\hline \multirow[t]{2}{*}{ FD } & 0.0537 & 0.0130 & -0.0720 & 0.00262 & -0.334 & -0.0638 & 0.149 \\
\hline & $(0.0741)$ & (0.0831) & (0.194) & $(0.0792)$ & $(0.223)$ & $(0.221)$ & (0.303) \\
\hline \multirow[t]{2}{*}{ Inopen } & -0.00197 & -0.00550 & 0.0397 & -0.00471 & -0.0350 & -0.0138 & 0.0498 \\
\hline & (0.00915) & $(0.0102)$ & $(0.0337)$ & (0.0108) & $(0.0328)$ & $(0.0262)$ & $(0.0453)$ \\
\hline \multirow[t]{2}{*}{$\operatorname{lninv}$} & $0.0204 * * *$ & -0.00909 & $0.0911 * *$ & $0.0226 * * *$ & 0.0332 & -0.00598 & 0.0449 \\
\hline & $(0.00507)$ & $(0.0114)$ & $(0.0390)$ & $(0.00855)$ & $(0.0224)$ & $(0.0221)$ & $(0.0283)$ \\
\hline \multirow[t]{2}{*}{ hc } & 0.0137 & -0.0446 & $0.280 * * *$ & 0.0254 & $0.119 * *$ & -0.0136 & 0.125 \\
\hline & $(0.0154)$ & $(0.0273)$ & $(0.107)$ & $(0.0251)$ & $(0.0537)$ & $(0.0625)$ & (0.106) \\
\hline \multirow[t]{2}{*}{ Gov_Stab } & $0.00856 * * *$ & & & & & & \\
\hline & $(0.00210)$ & & & & & & \\
\hline \multirow[t]{2}{*}{ Inv_Pro } & & $0.0183^{* * *}$ & & & & & \\
\hline & & $(0.00558)$ & & & & & \\
\hline \multirow[t]{2}{*}{ Corr } & & & $0.101 * *$ & & & & \\
\hline & & & $(0.0402)$ & & & & \\
\hline \multirow[t]{2}{*}{ Law_Order } & & & & $0.0398 * * *$ & & & \\
\hline & & & & $(0.00972)$ & & & \\
\hline \multirow[t]{2}{*}{ Mil_Pol } & & & & & $0.0623^{* *}$ & & \\
\hline & & & & & $(0.0247)$ & & \\
\hline \multirow[t]{2}{*}{ Demo_Acc } & & & & & & 0.0404 & \\
\hline & & & & & & $(0.0426)$ & \\
\hline \multirow[t]{2}{*}{ Bure_Qua } & & & & & & & 0.0703 \\
\hline & & & & & & & (0.0572) \\
\hline \multirow[t]{2}{*}{ Constant } & 0.00767 & -0.0822 & 0.394 & -0.0201 & $0.479 * *$ & -0.0100 & 0.368 \\
\hline & $(0.0476)$ & $(0.0648)$ & (0.259) & (0.0619) & (0.219) & (0.146) & $(0.335)$ \\
\hline Observations & 818 & 818 & 818 & 818 & 818 & 818 & 818 \\
\hline $\begin{array}{l}\text { Number of } \\
\text { code1 }\end{array}$ & 28 & 28 & 28 & 28 & 28 & 28 & 28 \\
\hline
\end{tabular}

Standard errors in parentheses, ${ }^{* * *} \mathrm{p}<0.01,{ }^{* *} \mathrm{p}<0.05,{ }^{*} \mathrm{p}<0.1$ 
Appendix 3: FD Growth Nexus with Interaction Institutional Quality

Standard errors in parentheses, ${ }^{* * *} p<0.01,{ }^{* *} p<0.05,{ }^{*} p<0.1$

\begin{tabular}{|c|c|c|c|c|c|c|c|}
\hline \multirow[b]{2}{*}{ VARIABLES } & (1) & (2) & (3) & (4) & (5) & (6) & (7) \\
\hline & \multicolumn{7}{|c|}{ Dependent Variable: Ingdppcw } \\
\hline \multirow[t]{2}{*}{ L.Ingdppcw } & $0.968 * * *$ & $0.975 * * *$ & $0.962 * * *$ & $0.965^{* * *}$ & $0.945^{* * *}$ & $0.966 * * *$ & $0.923 * * *$ \\
\hline & (0.00917) & (0.00919) & $(0.0112)$ & $(0.00944)$ & $(0.0136)$ & $(0.00915)$ & $(0.0207)$ \\
\hline \multirow[t]{2}{*}{ FD } & $-0.134 * *$ & $-0.201 * * *$ & $0.116^{* *}$ & $-0.211 * *$ & $-0.365^{* *}$ & -0.0120 & 0.0113 \\
\hline & $(0.0553)$ & $(0.0554)$ & $(0.0552)$ & $(0.0890)$ & $(0.176)$ & $(0.108)$ & $(0.0572)$ \\
\hline \multirow[t]{2}{*}{ Inopen } & 0.00324 & 0.00413 & 0.00727 & 0.00160 & 0.00629 & 0.00516 & $0.0201 * *$ \\
\hline & $(0.00713)$ & $(0.00678)$ & $(0.00812)$ & $(0.00720)$ & $(0.0101)$ & (0.00749) & $(0.00978)$ \\
\hline \multirow[t]{2}{*}{ Ininv } & $0.0237 * * *$ & $0.0205 * * *$ & $0.0229 * * *$ & $0.0235 * * *$ & $0.0295 * * *$ & $0.0243 * * *$ & $0.0363 * * *$ \\
\hline & $(0.00452)$ & $(0.00461)$ & $(0.00497)$ & $(0.00496)$ & $(0.00795)$ & $(0.00460)$ & $(0.00824)$ \\
\hline \multirow[t]{2}{*}{ hc } & $0.0382 * *$ & 0.0156 & $0.0352 * * *$ & $0.0460 * * *$ & $0.0721 * * *$ & $0.0394 * * *$ & $0.0573 * * *$ \\
\hline & $(0.0155)$ & $(0.0130)$ & $(0.00968)$ & $(0.0148)$ & $(0.0214)$ & $(0.0142)$ & $(0.0218)$ \\
\hline \multirow[t]{2}{*}{ Gov_Stab_FD } & $0.0198 * * *$ & & & & & & \\
\hline & $(0.00211)$ & & & & & & \\
\hline Inv_Pro_FD & & $\begin{array}{c}0.0340 * * * \\
(0.00312)\end{array}$ & & & & & \\
\hline Corr_FD & & & $\begin{array}{c}0.000587 \\
(0.0158)\end{array}$ & & & & \\
\hline Law_Order_FD & & & & $\begin{array}{c}0.0818^{* * *} \\
(0.0126)\end{array}$ & & & \\
\hline Mil_Pol_FD & & & & & $\begin{array}{c}0.0643^{* *} \\
(0.0256)\end{array}$ & & \\
\hline Demo_Acc_FD & & & & & & $\begin{array}{c}0.0149 \\
(0.0154)\end{array}$ & \\
\hline Bure_Qua_FD & & & & & & & $\begin{array}{c}0.116 * * * \\
(0.0431)\end{array}$ \\
\hline Constant & $\begin{array}{l}0.0863^{*} \\
(0.0495)\end{array}$ & $\begin{array}{l}0.0776 * \\
(0.0435)\end{array}$ & $\begin{array}{c}0.105^{*} \\
(0.0547)\end{array}$ & $\begin{array}{l}0.104 * * \\
(0.0437)\end{array}$ & $\begin{array}{c}0.196 * * * \\
(0.0746)\end{array}$ & $\begin{array}{l}0.0910^{*} \\
(0.0486)\end{array}$ & $\begin{array}{c}0.248 * * * \\
(0.0950)\end{array}$ \\
\hline Observations & 818 & 818 & 818 & 818 & 818 & 818 & 818 \\
\hline $\begin{array}{l}\text { Number of } \\
\text { code1 }\end{array}$ & 28 & 28 & 28 & 28 & 28 & 28 & 28 \\
\hline
\end{tabular}

